\title{
Consumers' Perception and Consumption of Sunflower Oil in Kumasi, Ghana
}

\author{
Fred Nimoh ${ }^{\mathrm{a}^{*}}$, Richmond Anaman $^{\mathrm{a}}$, Alhassan Abubakar ${ }^{\mathrm{a}}$, Bortey Manison $^{-}$ \\ BISHOP $^{a}$, AND DANIEL OPOKU DARKO ${ }^{a}$ \\ ${ }^{\text {a }}$ Department of Agricultural Economics, Agribusiness and Extension, PMB, UPO, KNUST, Kumasi, Ghana \\ ${ }^{*}$ Corresponding author \\ frediemoh@yahoo.com
}

Received: 4 July 2019; Published online: 18 April 2021 (A) Check for updates

\begin{abstract}
Consumption pattern among indigenous groups is usually influenced by consumers' sociocultural and perceptual factors. This study employs the binary logit model to analyse the factors that influence the consumption of sunflower oil in Kumasi, Ghana. A cross-sectional approach was used to obtain data from 200 consumers who were selected using a multi-stage sampling method. The results showed that a majority $(93 \%)$ of the respondents were aware of the availability of sunflower oil on the local market and a third $(69.5 \%)$ had used it for cooking before. The respondents agreed with the perception statements that sunflower oil is healthy, expensive, reduces the risk of heart diseases and cancer and has better frying performance. The empirical results of the logit regression model showed that consumption of sunflower oil is influenced by household size, awareness of the product and perceptions on health benefits, price and frying performance of sunflower oil. The price of the oil was identified as the most important constraint to its use albeit it had no negative effect on its consumption. Investments in the production and promotional strategies on the use of sunflower oil should consider the significant variables that have influence on its consumption.
\end{abstract}

Keywords: Sunflower oil; Perception; Consumption; Logit regression; Kumasi-Ghana

\section{Introduction}

Sunflower (Helianthus annuuss L.) is one of the few crop species that originated in North America (most originated in the fertile crescent of Asia, South or Central America) (Department of Agriculture, Forestry and Fisheries. (DAFF), 2010). Sunflower is a plant of the compositae family, a large family of flowering plants that are mainly herbs and shrubs. The plant's tolerance to drought and great variety of soils accounts for its suitability to most areas. The seeds of sunflower are rich in oil and it is considered to be a potential source of protein for human consumption; this due to its high ratio of polyunsaturated/saturated fatty acids and the high content of linoleic acid (Ohlson, 1992).

The oil extracted from sunflower seeds is a good source of oil for cooking and manufacturing of margarine, paints, soaps, and cosmetics as well as biodiesel. Oil concentration of sunflower seeds is about $44 \%$, on average (Andrianasolo, Debaeke, Champolivier \& Maury, 2016). In addition to the oil, edible proteins can be obtained from the cake for human consumption. The cake is also a good source of protein in the manufacture of furfural in yeast, alcohol production and as fuel. Sunflower oil production and distribution has been on the rise worldwide in recent years due to consumers becoming more particular about the food they eat and how it affects their health 
$186 \mid$ Nimoh et al.

and lifestyles. The Ghanaian consumption patterns have changed toward western (European and American) foods as a result of urbanization, women working outside the home and a shift in the lifestyles of a large youth population. Middleclass incomes are also rising and there is now higher demand for healthy foods. A growing concern among Ghanaian consumers with regard to food safety and healthy diets is also increasing the demand for higher quality products. As a result, domestic processors are developing and improving food products in order to meet the needs of this niche market (Hammond, 2014).

Ideally, the preparation and consumption of healthy meals provides good health and proper growth of individuals. Edible oil is one of the most important components of food and a major source of energy for human survival. Most households in Ghana use edible oils in the preparation of their daily meals. They are particularly high in saturated fat which contributes to coronary diseases when consumed in excess (Prema, 2013). In past years, the general government health expenditure has increased from US $\$ 53$ per capita in 1995 to US\$60 per capita in 2014 (Adua, Frimpong, Li \& Wang, 2017). Roberfroid (2000) reported that today's foods are intended not only to satisfy hunger and to provide necessary nutrients for humans but also to prevent nutritional diseases and improve physical and mental wellbeing of consumers. Sunflower oil is an excellent source of vitamin E (Warner, Vick, Kleingartner, Isaak \& Doroff, 2003). Sunflower oil gives consumers an even healthier food supply and lifestyle as it meets the needs of consumers and food processors alike for a healthy and high performance non-transgenic vegetable oil. The vitamin $\mathrm{E}$ in sunflower oil is a required nutrient that functions as an antioxidant and decreases the risk of heart disease, cancer and bolsters immune function (Grigg, 1999).

However, in Ghana there is high consumption of other edible oils compared to sunflower oil due to factors which are not precisely known and also because sunflower oil is a relatively new product on the Ghanaian market. Generally, people have negative perceptions and usually dislike new products on the market because of the uncertainty of the attributes of those products and the uncertain utility to be derived from the consumption of such products. This may account for consumers' preference for already existing products that they are familiar with. Awareness about a product's health benefits is needed to enhance consumer decision making on available products. Consumers are inadequately informed about the perceived sunflower oil health benefits; this could be a hindrance to the consumption of sunflower oil. Consumers' perceptions of the attributes of a product play a vital role on their purchase and consumption decisions (Nimoh, Asare, Twumasi \& Anaman, 2018). This study therefore sought to investigate consumers' awareness and perception of consumption of sunflower oil, and the factors affecting their consumption of the product as well the constraints to consumption in the Kumasi metropolis of Ghana. The study hypothesized that the consumption of sunflower oil is influenced by the socioeconomic characteristics of consumers such as age, education, household size and income, as well as their knowledge and perception about the product.

\section{Materials and Methods}

\subsection{Conceptual framework}

The study employed the random utility theory to explain a consumer's decision to consume sunflower oil among other edible oils available to the consumer. Random utility theory makes the assumption that every consumer is a rational decision-maker with the objective of maximizing his or her utility relative to the available choices and given constraints (Loureiro \& Umberger, 2007). That is, the decision-maker $i^{\text {th }}$ consumer in making a choice considers $M_{j}$ mutually exclusive alternatives that constitute his or her choice set which may differ according to the decision-maker. The $i^{\text {th }}$ consumer assigns to each alternative $j$ in his choice set a perceived utility $U_{j}^{i}$ and selects the alternative with the maximum utility (Anderson, De Palma \& Thisse, 1992). The utility assigned to each alternative (choices) depends on a number of measurable characteristics or attributes of the said alternative and of the decision-maker, specified as:

$U_{j}^{i}=U_{i}^{i}\left(X_{j}^{i}\right)$, where $X_{j}^{i}$ is the vector of attributes relative to alternative $j$ and to the decision- 
maker $i$. It is, however, acknowledged that consumers may take decisions that do not maximize their utility. This behaviour may result from errors in perception resulting from lack of information on product attributes or discounting inability or market failures such as price structure that do not reveal the real cost of the production to the society or limitation in the set of products available to the consumer (Tiffin, Bruce Traill \& Mortimer, 2006).

\section{$2.2 \quad$ Empirical model}

The logit model has been used in studies to determine factors affecting consumers' willingness to consume a product. The logit model is preferred over other categorical variable estimation techniques (Maddala, 1986) and is a better procedure for capturing the magnitude of the independent variable effect for qualitative dependent variables than the probit models (Amemiya, 1985). The logit is estimated using maximum likelihood estimation as it results in large-sample properties of consistency and asymptotic normality of the parameter estimates.

The logit model, based on the cumulative logistic probability function, was used to analyze the effect of factors that influence the consumer's consumption of sunflower oil (Pindyck \& Rubinfeld, 1988). The dependent variable is a dichotomous or binary choice, having two options of consuming sunflower and not consuming sunflower oil. The logit model is specified as follows:

$$
P i=F(Z i)=F(\alpha+\beta X i)=\frac{e^{\alpha+b X i}}{1+e^{\alpha+b X i}}
$$

The influence of consumers' socioeconomic characteristics and perception attributes of sunflower oil on their consumption behaviour was analyzed with the simple logit regression model. From equation 1 , the empirical specification of the logit model is given as:

$$
\begin{aligned}
& \text { Sunfloil }_{i j}=\beta_{0}+\beta_{1} \cdot \text { gend }_{i j}+\beta_{2} \cdot \text { age }_{i j}+ \\
& \beta_{3} \cdot \text { hdsize }_{i j}+\beta_{4} \cdot \text { mincome }_{i j}+\beta_{5} \cdot \text { education }_{i j}+ \\
& \beta_{6} \cdot \text { aware }_{i j}+\beta_{7} \cdot \text { healthier }_{i j}+\beta_{8} \cdot \text { expensive }_{i j}+ \\
& \beta_{9} \cdot \text { betterfrying }_{i j}+\beta_{10} \cdot \text { vitamin }_{i j}+\epsilon_{i}
\end{aligned}
$$

Table 1 presents the definition of explanatory variables used in the logit regression model.

\subsection{Population, sampling and data collection}

The target population was all edible oil consumers in Kumasi, Ghana. A multi-stage sampling technique was employed to select 200 consumers of edible oil from Kumasi metropolis. Kumasi metropolis was purposively selected because of its cosmopolitan nature. Three stage sampling was used to arrive at the respondents interviewed for the study. Stage one involved selection of sub-metros under Kumasi metropolis; stage two focused on selecting communities; and stage three focused on the respondents that participated in the survey. Four (4) sub-metros were purposively selected according to their income levels in the second stage. At the third stage, 50 vegetable oil consumers within each community were selected by using the systematic random sampling method based on every tenth residential address of the study communities. The faceto-face interview method was employed to obtain relevant responses from the sampled consumers using a semi-structured questionnaire made up of both open- and closed-ended questions. A pilot survey allowed for streamlining of the questions to achieve the objectives of the study. The face-to-face interviews provided the opportunity to explain the questions which were difficult for respondents to answer. This helped to obtain the accurate information required and also provided the opportunity for the interviewer to educate the respondents.

\subsection{Analysis}

Data were subject to both descriptive and inferential analyses. Data on the socio-economic characteristics of respondents and consumer evaluation of sunflower oil attributes were summarized with descriptive statistics, i.e. frequencies and percentages, graphs and mean scores. A perception index $(P I)$ was computed based on a 5 -point Likert scale $(1=$ strongly disagree to 5 = strongly agree) to assess consumers' perception of consumption of sunflower oil. The logit regres- 
Table 1: Definition of explanatory variables in the model

\begin{tabular}{|c|c|c|}
\hline Variable & Description of variable & $\begin{array}{l}\text { a priori } \\
\text { sign }\end{array}$ \\
\hline \multicolumn{3}{|c|}{ Dependent variable } \\
\hline Sunfloil & Willingness to consume sunflower oil (Willingness to consume $=1$, Otherwise $=0$ ) & \\
\hline \multicolumn{3}{|c|}{ Independent variables } \\
\hline Gend & Gender $($ Female $=1$, Male $=0)$ & + \\
\hline Age & Age of consumer (Years) & $+/-$ \\
\hline Hdsize & Household size (Number of people in the household) & + \\
\hline Mincome & Consumer's monthly income $(G H \phi)$ & + \\
\hline Education & Educational level (Number years in formal education) & + \\
\hline Aware & Awareness of sunflower oil $\left(Y e s=1, N_{o}=0\right)$ & + \\
\hline Healthier & Perception that sunflower oil is healthier compared to other refined edible oils (Yes $=1$, No $=0$ ) & + \\
\hline Expensive & Perception that sunflower oil is expensive than the other refined edible oils $(\mathrm{Yes}=1, \mathrm{No}=0$ ) & + \\
\hline Better frying & Perception that sunflower oil has better frying performance than other oils (Yes $=1$, No $=0$ ) & + \\
\hline Vitamin E & Perception that sunflower oil contains Vitamin E that reduces the risk of cancer $($ Yes $=1$, No $=0)$ & + \\
\hline
\end{tabular}

sion model was used to analyse factors that influenced the consumption of sunflower oil. Constraints to the consumption of sunflower oil in the study area were analyzed using the ranking and the Kendall Coefficient of Concordance (W).

\section{Results and Discussion}

\subsection{Socio-economic characteristics of respondents in the Kumasi Metropolis}

The majority of the respondents $(88 \%)$ were females (Table 2). This was due to the fact that there is high female participation in cooking in the traditional African household and that purchase of foodstuffs, including cooking oil is dominated by females in a household. The majority of the respondents $(62 \%)$ were married. This finding agrees with Basorun (2009) that cooking remains the exclusive responsibility of women that are married. The majority (90\%) of the respondents were Akans, the largest ethnic group in Ghana which comprise the Asante, Bono, Adanse, Twifo, Asen, Fante, Akuapem, Akyem, Akwamu, Kwahu, Sehwi, Awowin, Nzima and Ahanta. the majority of respondents were working as self-employed ( $71 \%$ of the sample). The mean age of respondents was 37 years, implying that most of the respondents were within the working age group. The size of a house- hold to a large extent determines both the frequency and amount of food that the house can purchase. Normally, the larger the household size, the greater the amount of food consumed as compared to smaller ones. The mean household size was approximately five persons. According to Stewart, Harris and Guthrie (2004), household size and a large number of dependents partly influence food choices. The average number of years of education among the respondents was 11 years, representing secondary level education, which is higher than the average Ghanaian schooling years of 5.16 (Ghana Living Standards Survey, 2005), signifying that most of the consumers captured in this study had high level of education. The average monthly income of respondents was GH\$582.95.

\subsection{Consumers' awareness and patronage of sunflower oil}

The majority of the respondents had knowledge about sunflower oil (93\%) and about its health benefits (80\%) (Figure 1), implying that consumers' awareness about sunflower could be an indication of a good market potential for the product. the majority of the respondents had purchased or used sunflower oil before (69.5\%) (Figure 2), implying that most of the respondents were familiar with the product. The main reasons for the patronage of the product were 
Perception and consumption of sunflower oil $\mid 189$



Source: Field survey, 2016

Figure 1: Awareness of sunflower and its health benefits

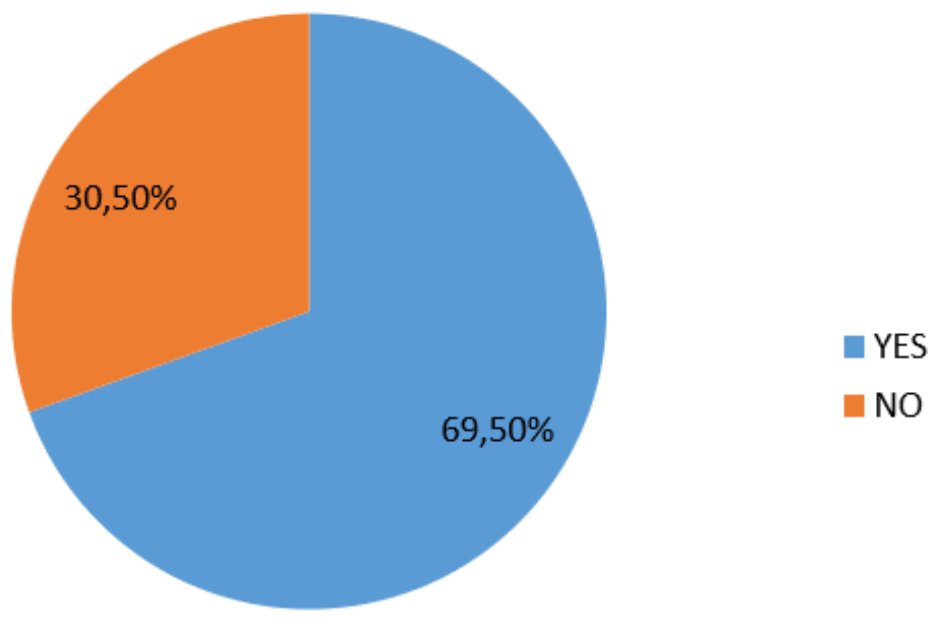

Source: Field survey, 2016

Figure 2: Patronage of sunflower oil 
$190 \mid$ Nimoh et al.

Table 2: Socioeconomic characteristics of respondents

\begin{tabular}{llll}
\hline Categorical Variables & Description & Frequency & Percentage \\
\hline Gender & Male & 25 & 12.5 \\
Marital Status & Female & 175 & 87.5 \\
& Single & 77 & 38.5 \\
Ethnic Group & Married & 123 & 61.5 \\
& Akan & 179 & 89.5 \\
& Ewe & 7 & 3.5 \\
Employment Type & Ga & 2 & 1.0 \\
& Northerners & 12 & 6.0 \\
& Government & 14 & 7.0 \\
& Self Employed & 142 & 71.0 \\
& Private & 16 & 8.0 \\
& Student & 15 & 7.5 \\
Continuous Variables & Mnemployed & 13 & 6.5 \\
Age & Minimum & Maximum & Mean \\
Household Size & 19 & 84 & 37.35 \\
Years in formal education & 0 & 15 & 4.73 \\
Income & 0 & 19 & 10.49 \\
\hline Source: Firdd & 3000 & 582.95 \\
\hline
\end{tabular}

Source: Field survey, 2016

mentioned as the health and nutritional attributes of the product. This finding agreed with that of Gracia and de Magistris (2008) for some consumers in south of Italy who indicated the health and nutrition perspectives as key in the purchasing of food.

\subsection{Consumers' perception of sunflower oil}

For consumers to accept and pay for a product, that particular product must possess attributes that are considered most important and attractive to them. Steenkamp and van Trijp (1996) suggested that a product's quality attributes form the basis for consumer preference for a product. The results from Table 3 showed that majority of the respondents agreed with the statements that sunflower oil is healthier compared to the other refined edible oil $(70 \%, 3.83)$; is of higher quality than other refined edible oils $(69 \%, 3.79)$; helps in reducing the risks of getting heart diseases $(51 \%, 3.62)$; and has better frying performance than other oils $(59.5 \%, 3.63)$.
However, about one-third $(29 \%, 3.32)$ of the respondents agreed with the statement that sunflower oil is rich in Vitamin E which reduces the risk of getting cancer, and majority $(74.5 \%, 3.93)$ also agreed with the statement that sunflower oil is more expensive than other refined edible oils. Averaging the six scores gave an overall perception index (PI) of 3.69, implying a good perception of consumption of sunflower oil.

\subsection{Factors affecting the consumption of sunflower oil}

The study found a significant difference in some of the socioeconomic characteristics of the respondents who consume sunflower oil and those who do not consume, particularly with gender and awareness of sunflower oil as well as their perception of the product, except the perception that sunflower oil contains Vitamin E that can reduce the risk of cancer (Table 4). Based on the empirical results from the logit regression model (Table 5), the variables found to influence the consumption of sunflower oil were household size, 
Perception and consumption of sunflower oil | 191

Table 3: Consumers' perception of sunflower oil

\begin{tabular}{|c|c|c|c|c|c|c|}
\hline Statements & $\begin{array}{c}\text { Strongly } \\
\text { disagree } \\
1\end{array}$ & $\begin{array}{c}\text { Disagree } \\
2\end{array}$ & $\begin{array}{c}\text { Undecided } \\
3\end{array}$ & $\begin{array}{c}\text { Agree } \\
4\end{array}$ & $\begin{array}{l}\text { Strongly } \\
\text { Agree } \\
5\end{array}$ & $\begin{array}{l}\text { Mean } \\
\text { Score }\end{array}$ \\
\hline $\begin{array}{l}\text { Sunflower oil is healthier than } \\
\text { other refined edible oil }\end{array}$ & 2 & 8 & 50 & 102 & 38 & 3.83 \\
\hline $\begin{array}{l}\text { Sunflower oil is expensive than } \\
\text { other refined edible oil }\end{array}$ & 0 & 14 & 37 & 98 & 51 & 3.93 \\
\hline $\begin{array}{l}\text { Sunflower oil is of higher quality } \\
\text { than other refined edible oils }\end{array}$ & 0 & 10 & 52 & 108 & 30 & 3.79 \\
\hline $\begin{array}{l}\text { Sunflower oil helps in reducing } \\
\text { the risks of getting heart diseases }\end{array}$ & 0 & 2 & 96 & 78 & 24 & 3.62 \\
\hline $\begin{array}{l}\text { Sunflower oil is rich in Vitamin E } \\
\text { which reduces the risk of getting cancer } \\
\text { Sunflower oil has better frying }\end{array}$ & 0 & 4 & 138 & 49 & 9 & 3.32 \\
\hline performance than other oils & 1 & 8 & 72 & 103 & 16 & 3.63 \\
\hline Perception Index & & & & & & 3.69 \\
\hline
\end{tabular}

Source: Field survey, 2016

Table 4: Descriptive statistics of respondents in the Kumasi Metropolis

\begin{tabular}{|c|c|c|c|c|}
\hline Independent variable & $\begin{array}{l}\text { Consume } \\
\text { sunflower } \\
\text { oil }\end{array}$ & $\begin{array}{l}\text { Not consume } \\
\text { sunflower } \\
\text { oil }\end{array}$ & $\begin{array}{c}\text { Mean } \\
\text { difference }\end{array}$ & Significance \\
\hline Age & 38.33 & 35.47 & 2.86 & 0.875 \\
\hline Gender & 0.92 & 0.7941 & $0.12^{* * *}$ & 0.000 \\
\hline Household Size & 4.86 & 4.49 & 0.37 & 0.595 \\
\hline Years in School & 10.64 & 10.25 & 0.39 & 0.668 \\
\hline Monthly Income & 597.80 & 400.44 & 197.36 & 0.768 \\
\hline Awareness & 0.99 & 0.81 & $0.18^{* * *}$ & 0.000 \\
\hline \multicolumn{5}{|l|}{ Perception Statements } \\
\hline Sunflower oil is healthier compared to other refined edible oils & 0.86 & 0.40 & $0.47^{* * *}$ & 0.000 \\
\hline Sunflower oil is expensive than the other refined edible oils & 0.88 & 0.50 & $0.38 * * *$ & 0.000 \\
\hline Sunflower oil has better frying performance than other oils & 0.77 & 0.26 & $0.51^{* * *}$ & 0.000 \\
\hline Sunflower oil contains Vitamin E that reduces the risk of cancer & 0.34 & 0.19 & 0.15 & 0.254 \\
\hline
\end{tabular}


$192 \mid$ Nimoh et al.

Table 5: Logit estimation of determinants of consumption of sunflower oil

\begin{tabular}{lcccc}
\hline Independent variables & Coefficient & $\begin{array}{c}\text { Standard } \\
\text { error }\end{array}$ & dy/dx & P-value \\
\hline Age & 0.0146 & 0.0180 & 0.0019 & 0.415 \\
Gender & 0.7909 & 0.5915 & 0.1046 & 0.181 \\
Household size & $0.1468^{*}$ & 0.0879 & 0.0194 & 0.095 \\
Years in school & 0.0560 & 0.0549 & 0.0074 & 0.308 \\
Monthly Income & 0.0003 & 0.0005 & 0.0000 & 0.573 \\
Awareness & $2.3728^{* *}$ & 1.1919 & 0.3137 & 0.047 \\
Sunflower oil healthier than other refined edible oils & $1.6856^{* * *}$ & 0.4357 & 0.2229 & 0.000 \\
Sunflower oil expensive than the other refined edible oils & $1.0415^{* *}$ & 0.4897 & 0.1377 & 0.033 \\
Sunflower oil has better frying performance than other oils & $1.1600^{* *}$ & 0.4721 & 0.1534 & 0.014 \\
Sunflower oil contains Vitamin E that reduces the risk of cancer & -0.1604 & 0.4639 & -0.0212 & 0.730 \\
Constant & $-6.6893^{* * *}$ & 1.7866 & & 0.000 \\
\hline Obs., 200; Pseudo R ${ }^{2}, 0.3427 ;$ Log likelihood, -84.2692 & & & & \\
\hline$*, * *, * * *:$ significance at 10\%, 5\% and 1\% respectively. Source: Authors' calculation, 2016 & &
\end{tabular}

respondents' awareness of the product and all the perception variables considered, except the perception that sunflower oil contains Vitamin E that can reduce the risk of cancer.

The variable household size, had a positive and statistically significant effect at $10 \%$ for the consumption of sunflower oil. An increase in household size tends to increase the consumption of sunflower oil by $1.94 \%$. This result is consistent with the finding by Ali, Aslam and Rasool (2013) who observed that household size significantly affects consumption edible oil. Also, awareness of sunflower oil as an edible oil product on the Ghanaian market was found to be positive and significant in affecting the consumption of sunflower oil at 5\% level. This implies that a unit change in the awareness of sunflower oil will increase the tendency of consumption of the product by $31.37 \%$. This finding agrees with result by Kathuria and Jit (2009) that the brand or product awareness is the consumer's ability to identify the brand and can be measured with the help of brand recall and brand recognition. In addition, consumers' perception that the product is healthier than other vegetable oils was positive and significant at $1 \%$, implying that the positive perception about the product tends to influence its consumption by $22.29 \%$. This supports the finding by Roberfroid (2000) who indicated that today's foods are not intended to only satisfy hunger and to provide necessary nutrients for humans but also to prevent nutrition-related diseases and to improve physical and mental wellbeing of the consumer. Therefore, consumers of sunflower oil view the product in respect of the disease preventing attribute as an important factor in deciding whether or not to patronize it. Moreover, the perception that sunflower oil has a better frying performance had a positive effect and tends to influence consumption of the product by $15.34 \%$. This implied that the use/cooking property of sunflower oil is of great concern to consumers in their choice of edible oil. This finding was in agreement with the findings of Steenkamp (1997). In spite of the perception that sunflower oil is more expensive than the other refined edible oils, the variable had a positive and significant influence on its consumption at $10 \%$ significance level. A unit change in the perception that sunflower oil is expensive will influence the consumption of the product by $13.77 \%$, implying the health consciousness of consumers irrespective of the price of the product.

\subsection{Constraints to the consumption of sunflower oil}

Table 6 presents results on the constraints to the consumption of sunflower oil. The majority of the respondents ranked price of sunflower oil as the most important constraint when pur-

IJFS | April 2021 | Volume 10 | pages 185-194 
Perception and consumption of sunflower oil | 193

Table 6: Constraints to the consumption of sunflower oil

\begin{tabular}{|c|c|c|c|c|c|c|c|}
\hline Constraints & $\begin{array}{c}\text { Most } \\
\text { Important } \\
1\end{array}$ & $\begin{array}{c}\text { More } \\
\text { Important } \\
2\end{array}$ & $\begin{array}{c}\text { Moderate } \\
\text { Moderate } \\
3\end{array}$ & $\begin{array}{c}\text { Slightly } \\
\text { Important } \\
4\end{array}$ & $\begin{array}{c}\text { Least } \\
\text { Important } \\
5\end{array}$ & $\begin{array}{l}\text { Mean } \\
\text { Mean }\end{array}$ & $\begin{array}{l}\text { Rank } \\
\text { Rank }\end{array}$ \\
\hline Price & 124 & 22 & 11 & 1 & 2 & 1.43 & $1 \mathrm{st}$ \\
\hline Advertisement & 18 & 29 & 26 & 7 & 3 & 2.86 & 2nd \\
\hline Preference & 26 & 26 & 22 & 18 & 15 & 3.66 & 3rd \\
\hline Package & 5 & 32 & 22 & 25 & 18 & 3.72 & 4 th \\
\hline Availability & 50 & 34 & 26 & 30 & 14 & 4.15 & 5 th \\
\hline Taste & 4 & 27 & 10 & 9 & 23 & 5.17 & 6 th \\
\hline
\end{tabular}

Kendall's W ${ }^{a}, 0.457$; Chi-square, 139.237; Df., 5.00; Asymp. Sig, 0.000

Source: Authors calculation, 2016

chasing sunflower oil, albeit this variable was not found to negatively affect the consumption of the product as per the empirical regression result (Table 5). Lack of advertisement or promotion of sunflower oil was found to be the second ranked concern to the low consumption of the product. The Kendall's Coefficient of Concordance $\left(\mathrm{W}^{a}\right)$ for the rankings of constraints faced by respondents was estimated at 0.457 , implying agreement of about half of the respondents with the order of ranking of the constraints.

\section{Conclusion}

From the findings of the study, it can be concluded that most consumers in the study area were aware of sunflower oil and its health benefits, and thus willing to consume the product albeit with the perception that it is more expensive than the other refined edible oils. The logit regression model showed that consumption of sunflower oil was influenced by household size, awareness of the product, perceptions on health benefits, price and frying performance. Price was considered to be the important constraint to the consumption of sunflower oil although it did not have negative effect on its consumption. There is a need to promote the consumption of sunflower to help improve the health of consumers. However, producers need to consider the socioeconomic and perception factors influencing its consumption in an attempt to promoting its use. Manufacturers and retailers must promote and develop new product design and marketing strategies of the sunflower oil product based on its health benefits and frying performance whilst considering the price to increase their market share.

\section{References}

Adua, E., Frimpong, K., Li, X. \& Wang, W. (2017). Emerging issues in public health: A perspective on Ghana's healthcare expenditure, policies and outcomes. EPMA Journal, 8(3), 197-206. doi:10 . $1007 /$ s13167-017-0109-3

Ali, Z., Aslam, M. \& Rasool, S. (2013). Factors affecting consumption of edible oil in Pakistan. IOSR Journal of Business and Management, 15(1), 87-92.

Amemiya, T. (1985). Advanced econometrics. Harvard University Press.

Anderson, S. P., De Palma, A. \& Thisse, J.-F. (1992). Discrete choice theory of product differentiation. MIT press.

Andrianasolo, F. N., Debaeke, P., Champolivier, L. \& Maury, P. (2016). Analysis and modelling of the factors controlling seed oil concentration in sunflower: A review. $O C L$, $23(2)$, D206.

Basorun, J. O. (2009). Analysis of the relationships of factors affecting rice consumption in a targeted region in Ekiti-state, Nigeria. Journal of Applied Quantitative Methods, $4(2)$. 
Department of Agriculture, Forestry and Fisheries. (DAFF). (2010). Sunflower production guide. Resource Centre Directorate Agricultural Information Services. South Africa.

Ghana Living Standards Survey. (2005). Report of the Fourth Round (GLSS 4).

Gracia, A. \& de Magistris, T. (2008). The demand for organic foods in the South of Italy: A discrete choice model. Food Policy, 33(5), 386-396. doi:10 . $1016 / \mathrm{j}$. foodpol . 2007.12 .002

Grigg, D. (1999). The fat of the land: A geography of oil and fat consumption. GeoJournal, 48(4), 259-268.

Hammond, D. E. (2014). Consumers perception of attributes and related benefits of soy and its consumption in Ghana (Doctoral dissertation).

Kathuria, L. M. \& Jit, B. (2009). An empirical study on brand awareness and the factors influencing brand loyalty towards hair shampoos. IUP Journal of Brand Management, 6 .

Loureiro, M. L. \& Umberger, W. J. (2007). A choice experiment model for beef. What US consumer responses tell us about relative preferences for food safety, countryof-origin labeling and traceability. Food Policy, 32(4), 496-514. doi:10 . 1016/j . foodpol.2006.11.006

Maddala, G. S. (1986). Limited-dependent and qualitative variables in econometrics. Cambridge university press.

Nimoh, F., Asare, G. O., Twumasi, I. \& Anaman, R. (2018). Consumers willingness to consume cassava leaves as a leafy vegetable in the Kumasi Metropolis, Ghana. International Journal of Food Studies, 7(2).

Ohlson, R. (1992). Modern processing of rapeseed. Journal of the American Oil Chemists Society, 69(3), 195-198. Symp at the 1991 Annual Meeting of the American Oil Chemists Soc : Oilseed Processing for Edible Food and Feed Products, Chicago, Il, May, 1991. doi:10.1007/BF02635885

Pindyck, R. S. \& Rubinfeld, D. L. (1988). Econometric models and economic forecasts.

Prema, R. (2013). An empirical study on brand preference towards edible oil in rural areas with special reference to coimbatore district. Indian journal of applied research, 3(3), 223-227.

Roberfroid, M. B. (2000). A European consensus of scientific concepts of functional foods. Nutrition (Burbank, Los Angeles County, Calif.) 16(7-8), 689-691.

Steenkamp, J.-B. E. M. (1997). Dynamics in consumer behavior with respect to agricultural and food products. In Agricultural marketing and consumer behavior in a changing world (pp. 143-188). Springer.

Steenkamp, J.-B. E. M. \& van Trijp, H. C. M. (1996). Quality guidance: A consumerbased approach to food quality improvement using partial least squares. European Review of Agricultural Economics, 23(2), 195-215.

Stewart, H., Harris, J. M. \& Guthrie, J. F. (2004). What determines the variety of a household's vegetable purchases?

Tiffin, R., Bruce Traill, W. \& Mortimer, S. (2006). Food choice in an interdisciplinary context. Journal of Agricultural Economics, 57(2), 213-220.

Warner, K., Vick, B., Kleingartner, L., Isaak, R. \& Doroff, K. (2003). Compositions of sunflower, Nusun (mid-oleic sunflower) and high-oleic sunflower oils. In Proc. sunflower res. workshop, fargo, nd (pp. 16-17). National Sunflower Assoc. Mandan, ND. 